\title{
Denis Hermann. Quelques remarques à propos de l'interprétation du sens du rokn-e rābe' chez Mohammad Bāqer Hamadānī, le fondateur de l'école shaykhī hamadānī
}

\section{Fabrizio Speziale}

\section{(2) OpenEdition}

\section{Journals}

Édition électronique

URL : http://journals.openedition.org/abstractairanica/40296

DOI : 10.4000/abstractairanica.40296

ISSN : 1961-960X

Éditeur :

CNRS (UMR 7528 Mondes iraniens et indiens), Éditions de l'IFRI

Édition imprimée

Date de publication : 1 décembre 2013

ISSN : 0240-8910

\section{Référence électronique}

Fabrizio Speziale, «Denis Hermann. Quelques remarques à propos de l'interprétation du sens du rokne rābe' chez Mohammad Bāqer Hamadānī, le fondateur de l'école shaykhī hamadānī », Abstracta Iranica [En ligne], Volume 32-33 | 2013, document 363, mis en ligne le 01 juillet 2016, consulté le 29 septembre 2020. URL : http://journals.openedition.org/abstractairanica/40296 ; DOI : https://doi.org/ 10.4000/abstractairanica.40296

Ce document a été généré automatiquement le 29 septembre 2020.

Tous droits réservés 


\title{
Denis Hermann. Quelques remarques à propos de l'interprétation du sens du rokn-e rābe' chez Mohammad Bāqer Hamadānī, le fondateur de l'école shaykhī hamadānī
}

\author{
Fabrizio Speziale
}

\section{RÉFÉRENCE}

Denis Hermann. «Quelques remarques à propos de l'interprétation du sens du rokn-e rābe chez Mohammad Bāqer Hamadānī, le fondateur de l'école shaykhī hamadānī ». Journal Asiatique, 295/2, 2007, p. 461-491.

1 Cet article constitue la première publication qui revient sur la branche hamadānī (également connue sous le nom de jandaqī ou mīrzā bāqiriyya) de l'école šayHī, constituée à la mort de Muhammad Karīm H̦ān Kirmānī en 1288/1871.

2 Cette étude examine notamment une particularité doctrinale majeure des šayH̄i hamadānī, soit leur interprétation du rukn-i raba' (le quatrième pilier), à travers une analyse de la pensée de Muhammad Bāqir Hamadānī (m. 1319/1901), le fondateur de la branche hamadānī. 


\section{AUTEURS}

\section{FABRIZIO SPEZIALE}

Université Sorbonne Nouvelle-Paris 3, Mondes iranien et indien, Paris 